\title{
Potensi Dan Peluang Pengembangan Komoditas Ubi Jalar Di Kabupaten Kerinci Provinsi Jambi
}

\author{
Suharyon dan Safri Edi \\ Balai Pengkajian Teknologi Pertanian (BPTP) Jambi \\ Email: suharyonhariyon@mail.com
}

\begin{abstract}
ABSTRAK
Ubi jalar sangat bermanfaat untuk kesehatan manusia dan potensial sebagai sumber pangan pengganti beras. Umbi bersama brangkasan juga dapat dimamfaatkan sebagai pakan ternak. Pada umumnya petani mengembangkan usahatani ubu jalar sebatas pemahaman yang dikuasai secara turun temurun, sehingga produktivitas yang dicapai jauh lebih rendah dari haasil teknologi peningkatan produktivitas yang sudah dilakukan mdelalu penelitian/pengkajian. Perlu ketersedeaan teknologi budidaya ditingkat petani melalui penerapan PTT yang diyakini dapat meningkatkan produktivitas ubi jalar. Berbagai langkah operasional yang dilakukan mengembangan ubi jalar antara lain penyediaan bibit bermutu, pemakaian varietas unggul, pemupukan berimbang, penyediaan sarana produksi, pengendalian organisme pengganggu tanaman (OPT) serta penanganan panen dan pasca panen.
\end{abstract}

Kata Kunci: Potensi, Peluang, Ubi Jalar

\section{PENDAHULUAN}

\section{Latar Belakang}

Ubi jalar (Ipomoea batatas L.) atau dikenal juga dengan istilah ketela rambat merupakan tanaman yang termasuk ke dalam jenis tanaman palawija, dapat berfungsi sebagai pengganti bahan makanan pokok (beras) karena merupakan sumber karbohidrat. Provinsi Jambi merupakan salah satu daerah sentra dan penghasil komoditas ubi jalar. Selama periode 2014-2017, produksi ubi jalar di Provinsi Jambi meningkat dengan rata-rata 1,90\% / tahun. Komoditas ubi jalar memegang peranan yang cukup penting karena mempunyai banyak manfaat dan nilai tambah. Ubi jalar merupakan salah satu penghasil karbohidrat (sebagai sumber energi) yang potensial dan dapat digunakan sebagai sumber pangan alternatif (selain nasi), bahan pembuatan pakan dan bahan industri. Nilai tambah dari ubi jalar cukup banyak yang dapat diperoleh dengan cara pengolahan ubi jalar segar menjadi tepung, selai, keripik, mie, sitk dan saos., gula permanen, obat-obatan, cuka, manisan kering, kecap, lem, dan pakan. Varian dari tepung ubi jalar diantaranya: kue kering (cookies), kue bolu (cake), ice cream, roti manis, juice dan bakpia.

Peranan usahatani ubi jalar memiliki prospek yang baik sebagai komoditas pertanian unggulan tanaman palawija. Potensi produksi bisa mencapai $\pm 20-30$ ton per hektar dan saat ini ubi jalar merupakan tanaman ubi-ubian yang paling produktif. Menurut data BPS Provinsi Jambi (2015), luas panen, produksi dan produktivitas menurut Kabupaten/Kota ubi jalar di Kabupaten Kerinci mencapai luas panen 2.194 
ha dengan produksi 71.035 ton dan produktivitas mencapai $325.00 \mathrm{kuintal} / \mathrm{ha}$ yang dapat menyumbang produksi di Provinsi Jambi. Dan merupakan penyebaran salah satu sentra komoditas ubi jalar terbesar di Provinsi Jambi.

Secara finansial usahatani ubi jalar di Kabupaten Kerinci pada dasarnya lebih menguntungkan dibandingkan dengan komoditas lain, seperti padi, ubi kayu dan jagung. Hal ini sesuai dengan hasil penelitian Edison, dkk (2015), Akibat kurangnya peluang pasar, jenis dan intensitas pengolahan ubi jalar penguasaan teknologi yang belum optimal, sering terjadinya fluktuasi harga yang sangat tajam dan menyebabkan produktivitas yang belum maksimal. Apabila ubi jalar dapat dianekaragamkan cara pengolahannya, maka akan mendorong permintaan terhadap ubi jalar dan pada akhirnya akan mendorong harga atau menstabilkan harga sehingga akan memacu petani untuk menanam ubi jalar secara intensif (Perda Kabupaten Ker4inci, 2017).

Sentra ubi jalar di Kabupaten Kerinci pada mulanya hanya ternbatas di Kecamatan Siulak. Pengembangan komoditas ubi jalar Kabupaten Kerinci meluas ke Kecamatan lain, seperti Kecamatan kayu Aro, Bedeng VIII dan lainya (Dinas Pertanian, 2015). Meluasnya pengembangan komoditas ubi jalar di Kabupaten Kerinci disebabkan karena selain wilayahnya mempunyai struktur agroklimat yang mendukung juga dipacu oleh munculnya industri pengolahan makanan yang memanfaatkan bahan dasarnya ubi jalar oleh Ibu PKK.

Pengembangan komoditas unggulan (ubi jalar) berorientasi agribisnis di Kabupaten Kerinci dengan didukung oleh luasnya lahan sawah (irigasi teknis, setengah teknis, sederhana dan tadah hujan) merupakan sektor terpenting yang dapat dan perlu diupayakan guna meningkatkan pendapatan masyarakat. Akan tetapi, pengembangan tersebut di masa sekarang dan yang akan datang akan dihadapkan pada berbagai tantangan yang semakin berat dan kompleks.

Kemajuan agribisnis komoditas unggulan sangat tergantung dari kekuatan dan kemauan seluruh masyarakat (pelaku utama, pelaku usaha, stakeholder dan pemerintah) untuk mengembangkan komoditas unggulan khususnya ubi jalar dalam rangka meningkatkan pendapatan para petani Peran masyarakat agribisnis dalam persaingan baik pasar lokal, regional maupun dunia masih sangat kurang. Oleh karena itu, upaya dan kemauan masyarakat pertanian dalam mengembangkan komoditas unggulan agribisnis sangat diperlukan.

Sehubungan dengan pentingnya Pengembangan Komoditas Ubi Jalar Berbasis Agribisnis, maka perlu dilakukan serangkaian penelitian untuk menyusun Strategi Pengembangan Komoditas Ubi Jalar (Ipomoea batatas L.) Berbasis Agribisnis sehingga diperoleh hasil yang diharapkan.

\section{Petensi, Peluang Pengembangan Ubi Jalar}

Provinsi Jambi sebagai bagian dari wilayah Indonesia memiliki potensi dan peluang dilihat dari sumber daya alam yang relatif besar untuk mendukung perkembangan industri pengolahan hasil pertanian atau agroindustri. Salah satu bentuk agroindustri 
yang dapat dikembangkan adalah agroindustri komoditi ubi jalar. Provinsi Jambi khususnya Kabupaten Kerinci menghasilkan ubi jalar lebih banyak dibandingkan yang lain, secara terperinci luas panen, produksi dan produktivitas ubi jalar di Provinsi Jambi dapat dilihat pada Tabel 1.

Tabel 1. Luas Panen, Produksi dan Produktivitas Ubi Jalar menurut Kabupaten/Kota Tahun 2014

\begin{tabular}{|l|c|c|c|}
\hline pupaten /Kota & $\begin{array}{c}\text { Luas Panen } \\
\text { (ha) }\end{array}$ & duksi (ton) & $\begin{array}{c}\text { Produktivit } \\
\text { as(kw/ha) }\end{array}$ \\
\hline Kerinci & 2.194 & 71.305 & 325,00 \\
\hline Merangin & 321 & 3.624 & 112,90 \\
\hline Sarolangun & 38 & 302 & 79,59 \\
\hline Batang Hari & 20 & 152 & 75,97 \\
\hline Muaro Jambi & 98 & 770 & 78,53 \\
\hline Tanjab Timur & 122 & 936 & 76,76 \\
\hline Tanjab Barat & 29 & 211 & 72,77 \\
\hline Tebo & 29 & 213 & 73,37 \\
\hline Bungo & 52 & 436 & 83,81 \\
\hline Kota Jambi & 16 & 125 & 78,00 \\
\hline Sungai Penuh & 26 & 602 & 231,59 \\
\hline Jumlah/Total & 2.945 & 78.676 & 267,15 \\
\hline
\end{tabular}

Sumber: BPS Provinsi Jambi, 2015

Tabel 1 menunjukkan bahwa hasil produktivitas ubi jalar di Kabupaten Kerinci sebesar 325,00 kw/ha adalah paling banyak dibandingkan dengan Kabupaten lainnya. Dengan jumlah produksi ubi jalar terbanyak, Kabupaten Kerinci memiliki potensi sumber daya alam yang relatif besar untuk mendukung perkembangan industri pengolahan ubi jalar. Kabupaten Kerinci khususnya di Kecamatan Siulak merupakan salah sentral agroindustri ubi jalar, jumlah agroindustri ubi jalar di Kecamatan Kayu Aro lebih banyak dibandingkan dengan Kecamatan lainnya, yaitu sebanyak 7 agroindustri ubi jalar (Dinas Perindustrian dan Perdagangan Provinsi Jambi Tahun 2015). Kegiatan sektor industri di Kabupaten Kerinci masih didominasi oleh industri kecil yang pada umumnya merupakan industri rumah tangga. Kabupaten Kerinci bukan merupakan kawasan industri, tetapi merupakan kawasan pertanian dan jenis industri terbesar yang ada di Kabupaten Kerinci adalah agroindustri pangan dan non pangan.

Tanaman pangan yang berpotensi sebagai sumber pangan antara lain padi, jagung, ubi kayu, ubi jalar, kacang-kacangan, kedelai, dan lain-lain. Ubi jalar merupakan salah satu komoditas tanaman pangan yang memberikan sumbangan terhadap PDB yang cukup signifikan dan terus meningkat dalam beberapa tahun terakhir. Disamping itu juga komoditi ini telah memberikan sumbangan terhadap devisa negara melalui ekspor dalam bentuk tepung. Net ekspor-impor ubi jalar 
adalah satu-satunya komoditas tanaman pangan yang selalu positif. Ubi jalar menjadi salah satu dari dua puluh jenis pangan yang berfungsi sebagai sumber karbohidrat. Ubi jalar bisa menjadi salah satu dari sekian tanaman pangan yang alternatif untuk mendampingi beras menuju ketahanan pangan. Hal ini didasarkan pada pertimbangan bahwa ubi jalar merupakan (1) sumber karbohidrat keempat setelah padi, jagung dan ubi kayu; (2) memiliki produktivitas tinggi dibandingkan dengan beras dan ubi kayu;

(3) memiliki potensi diversifikasi produk yang cukup beragam; (4) memiliki potensi permintaan pasar baik lokal, regional maupun ekspor yang terus meningkat; (5) serta memiliki kandungan gizi yang cukup beragam dan tidak dimiliki oleh tanaman pangan lainnya (Defri, 2011).

Pada saat ini budidaya ubi jalar sangatlah mudah untuk dilakukan oleh petani, dapat ditanam disawah maupun diladang. Total luas panen ubi jalar di Indonesia pada tahun 2011 mencapai177.040 hektar dengan tingkat produksi sebesar 1.887.005 ton dan produktivitasnya mencapai 10,66 ton per hektarnya (Badan Pusat Statistik Indonesia, 2011). Hal ini juga dirasakan Provinsi Jambi yang tingkat produksi ubi jalarnya meningkat ditiap tahunnya (Dinas Pertanian Tanaman Pangan Provinsi Jambi, 2012). Pengembangan potensi ubi jalar pun tersebar diseluruh Kabupaten di Provinsi Jambi. Berdasarkan sentra produksinya, produksi ubi jalar terbesar di Provinsi Jambi adalah Kabupaten Kerinci, Merangin dan Tanjung Jabung Timur. Dari ketiga kabupaten tersebut, Kabupaten Kerinci merupakan daerah penghasil ubi jalar terbesar di Provinsi Jambi dengan rata-rata produktivitasnya hanya mencapai 32,24 ton per hektar (Dinas Pertanian Tanaman Pangan Kabupaten Kerinci, 2012).Kecamatan Kayu Aro merupakan wilayah dataran tinggi yang memiliki tingkat kesuburan tanah yang relatif baik, sehingga dikenal sebagai daerah pertanian. Kayu Aro merupakan kecamatan penghasil ubi jalar terbesar di Kabupaten Kerinci (Dinas Pertanian Tanaman Pangan Kabupaten Kerinci, 2012).Akan tetapi produktivitas optimal ubi jalar seharusnya dapat mencapai 40 ton per hektar (Purwonodan Purnamawati, 2013), mengingat keadaan alam dan topografi Kabupaten Kerinci yang sangat ubur dengan jenis tanah yang sebagian besarnya berjenis andosol, dengan kelembaban udara $65-97 \%$ serta suhu udara antara $18-29^{\circ} \mathrm{C}$ yang sangat cocok dengan ubi jalar.

Untuk mencapai produksi yang optimal bahkan maksimal harus didukung dengan beberapa faktor yang mempengaruhi produksi seperti lahan, bibit, pupuk, herbisida, dan tenaga kerja). Adapun tujuan penelitian adalah untuk mengetahui signifikansi dan besarnya pengaruh faktor produksi lahan, tenaga kerja, bibit, dan herbisida terhadap produksi ubi jalar di Kecamatan Kayu Aro Kabupaten Kerinci.

\section{Manfaat dan Sosial Ekonomi Ubi Jalar}

Ubi jalar merupakan varietas yang memiliki umbi tidak berserat, produktivitas 20-30 ton/ha, dan banyak diusahakan pada daerah dengan ketinggian 400-600 m dpl seperti 
Kecamatan Kayu Aro, Kecamatan Siulak (Dinas Pertanian Kab.Kerinci 2017). Ubi jalar memiliki peluang cukup besar untuk dikembangkan karena memiliki daya adaptasi terhadap kondisi lahan dan lingkungan.

Manfaat dan keunggulan dari ubi jalar menurut kurnia (2010) adalah ubi jalar memiliki indeks glikemiks 54 yang tergolong rendah yang berarti karbihidratnya tidah mudah diubah menjadi gula sehingga sangat baik dikonsumsi untuk penderita diabetes. Mengkonsumsi ubi jalar tidak meningkatkan kadar gula darah secara drastis karena kadar karbohidrat di dalamnya termasuk rendah (hasyim dan Yusup, 2008). Selanjutnya Suyanto et al (2012) mengatakan kandungan gizi makro dan mikro berdasarkan kebutuhan karbohidrat untuk orang dewasa perhari lebih baik dari beras. Menurut Ginting (2009); Widowati dan Wagiono (2012) ubi jalar mengandung berbagai vitamin A, B1, B2, B3 dan Vitamin C.

Dari aspek sosial, bahwa Ibu rumah tangga memiliki peranan dalam pemenuhan gizi keluarga, dimulai dari aktivitas pemanfaatkan lahan pekarangan, budidaya tanaman, sampai proses pasca panen.Tiap desa telah terbentuk kelembagaan petani yang anggotanya terdiri dari ibu rumah tangga. Kelembagaan ini dikenal dengan nama Kelompok Wanita Tani (KWT), yang berperan sebagai organisasi dalam pelaksanaan budidaya padi, sayuran, ikan dan ternak.Kelompok tani berperan untuk dapat menjalankan kegiatan yang lebih terorganisir, mulai dari menyiapan lahan, menyediakan pupuk, penanaman, perawatan dan panen. Ibu rumah tangga merupakan potensi sumber daya manusia dalam kegiatan M-KRPL (Kawasan rumah pangan lestari).

Ditambahkan juga dari hasil Laporan Penggerak PKK (2019) yang disebutnya Pemanfaatan Hatinya PKK Desa Mekar Sari Kabupaten Kerinci (2019) dilihat berdasarkan indikator antara lain capaian rumah yang memanfaatkan Hatinya PKK dengan peningkatan ekonomi keluarga, capaian industri Rumah Tangga, Kader Pangan, Kader Toga, Kelompok Tani Perempuan yang aktif (Tabel 2).

\begin{tabular}{|c|l|c|}
\hline No. & \multicolumn{1}{|c|}{ Komponen } & 2018 \\
\hline 1 & Jumlah Kader & \\
& Pangan & 16 orang \\
& Sandang & 16 orang \\
& Perumahan dan Tata Laksana & 16 orang \\
\hline 2 & Pangan Makanan Pokok Beras Non Beras & 1.797 Jiwa \\
& Peternakan & 345 rumah \\
& Perikanan & 360 rumah \\
& Warung Hidup & 360 rumah \\
& Lumbung Hidup & 355 rumah \\
& Toga & 405 rumah \\
& Tanaman Hias & 312 rumah \\
\hline 3 & Jumlah Industri Rumah Tangga Pangan & 4 unit \\
\hline
\end{tabular}




\begin{tabular}{|l|l|l|}
\hline & Sandang Lain-lain & \\
\hline 4 & -Jumlah Rumah Rumah Sehat dan Layak & 405 unit \\
& Huni Rumah kurang sehat dan tidak layak \\
huni & Tidak ada \\
\hline
\end{tabular}

\section{Teknologi Peningkatan Produktivitas Ubi Jalar}

Keberhasilan peningkatan produktivitas ubi jalar ditentukan oleh beberapa faktor trknis diantaranya varietas, pupuk, dan pengolahan budidaya sangat menentukan varietas dan bibit merupakan dua kata kunci yang tidak bisa dipisahkan dalam suatu usaha pertanian supaya berjalan efektif dan efisien. Varietas yang digunakan dalam usaha ubi jalar hendaknya varietas unggul yang sesuai beradaptasi baik pada lingkungan setempat. Disamping itu bibit sebagai pembawa potensi genetic suatu varietas juga harus memeiliki mutu (genetika, fisikdan fisiologik) yang tijnggi agar ekspresi dan potensi genetic dapat diperoleh. Menurut Taher (2005) faktor yang selalu menjadi perhatian dalam pengembangan varietas baru adalah yang berkaitan dengan produktivitas dan mutu serta efisien dalam system produksi, dengan kata lain upaya pengembangan varietas-varietas unggul baru perlu memenuhi kebutuhan perkembangan permintaan pengguna atau konsumen.

Pembinaan system pembibitan ubi jalar dalam upaya pengembangannya, terutama di wilayah-wlayah pengembangan baru perlu mendapat perhatian yang lebih memadai, pemerintah telah membangun berbagai kelembagaan bibit yang menangani kegiatan mulai dari penelitian dan pemuliaan (Badan Litbang Pertanian), pelepasan varietas (Badan Benih Nasional), kebijaksanaan opetrasional dan bimbingan teknis produksi (Direktorat Perbenihan), produksi benih (BBI/BBU), serta pemgawasan mutu dan sertifikasi (BPSB).

Tabel 3. Varietas Unggul Ubi Jalar yang Sudah Dilepas Menjadi Varietas di Indonesia

\begin{tabular}{|c|l|c|c|c|c|}
\hline No. & Varietas & $\begin{array}{c}\text { Tahun } \\
\text { Dilepas }\end{array}$ & $\begin{array}{c}\text { Umur } \\
\text { (Bulan) }\end{array}$ & $\begin{array}{c}\text { Hasil } \\
(\text { Ton/ha) }\end{array}$ & Keunggulan \\
\hline 1 & Daya & 1977 & 4 & 23 & Agak tahan hama boleng \\
\hline 2 & Borobudur & 1982 & $3,5-4$ & 20 & Tolleran hama penggerek \\
\hline 3 & Prambanan & 1982 & $3,5-4$ & 28 & $\begin{array}{l}\text { Daya adaptasi luas, toleran } \\
\text { penyakit kudis }\end{array}$ \\
\hline 4 & Mendut & 1989 & 4 & 35 & $\begin{array}{l}\text { Mampu beradptasi dilahan } \\
\text { marginal, tumbuh 900 m } \\
\text { dpl }\end{array}$ \\
\hline 5 & Kalasan & 1991 & $3-4$ & 40 & $\begin{array}{l}\text { Agak tahan karat daun, } \\
\text { mampu beradaptasi pada } \\
\text { lahan marginal }\end{array}$ \\
\hline
\end{tabular}




\begin{tabular}{|c|l|c|c|c|l|}
\hline 7 & Muara Takus & 1995 & $4,4-5$ & $30-35$ & $\begin{array}{l}\text { Tahan terhadap penyakit } \\
\text { kudis }\end{array}$ \\
\hline 8 & Czangkuang & 1998 & $4,4-5$ & $30-31$ & Agak tahan hama bolang \\
\hline 9 & Sewu & 1998 & $4,4-5$ & $23-30$ & Agak tahan hama bolang \\
\hline 10 & Sari & 1998 & $4,4-5$ & $30-35$ & Agak tahan hma bolang \\
\hline 11 & Boko & 2001 & $4,4-5$ & $30-35$ & Agak tahan hama bolang \\
\hline
\end{tabular}

Sumber: Jusuf et al, (2012); Rahayuningsih dan Wahyuni (2012)

Peningkatan produktivitas ubi jalar disarankan meneapkan pengelolaan tanaman terpadu (PTT). Menurut Pislitbangtan (2012) penerapan PTT ubi jalar diyakini meningkatkan produktivitas. Penerapan PTT ubi jalar secara teknis adalah penggunaan varietas unggul. Panjang stek $20-25 \mathrm{~cm}$. Sebelum ditanam stek direndam dengan larutan mancozeb $80 \%$ dan insektisida karbpsulfan selama lima menit. Stek ditanam diatas bedengan. Guludan tunggal 50-60 cm, jarak antar gludan 80-100 cm, jarak antar guludan 80-100 cm. Pupuk organic (pupuk kandang 10 ton/ha), diberikan saat pengolahan tanah (saat pembuatan guludan).

Dikemukan Edison dan kawan-kawan (2017) bahwa ketersediaan ubi jalar sebagai bahan baku utama dalam industri pengolahan ubi jalar tergantung pada musim (risiko alam), dimana budidaya tanaman ubi jalar dilakukan selama 3 - 3,5 bulan. Kondisi ini menyulitkan pengusaha untuk menjaga kelangsungan usaha. Untuk mengatasi ketersediaan bahan baku, pengusaha akan membeli ubi jalar pada petani dalam jumlah yang cukup banyak. Selain risiko musiman, Agroindustri.

\section{KESIMPULAN}

Ubi jalar sangat bermanfaat untuk kesehatan manusia dan potensial sebagai sumber pangan pengganti beras. Umbi bersama brangkasan juga dapat dimamfaatkan sebagai pakan ternak. Pada umumnya petani mengembangkan usahatani ubi jalar sebatas pemahaman yang dikuasai secara turun temurun, sehingga produktivitas yang dicapai jauh lebih rendah dari haasil teknologi peningkatan produktivitas yang sudah dilakukan melalu penelitian/pengkajian. Perlu ketersedeaan teknologi budidaya ditingkat petani melalui penerapan PTT yang diyakini dapat meningkatkan produktivitas ubi jalar. Berbagai langkah operasional yang dilakukan mengembangan ubi jalar antara lain penyediaan bibit bermutu, pemakaian varietas unggul, pemupukan berimbang, penyediaan sarana produksi, pengendalian organisme pengganggu tanaman (OPT) serta penanganan panen dan pasca panen.

\section{DAFTAR PUSTAKA}

Anonimous, 2019. Pemanfaatan (Hatinya PKK) Tim Penggerak PKK Kabupaten

Kerinci. Laporan Pelaksanaan Pemanfatan Hatinya PKK Kabupaten Kerinci Provinsi Jambi. 2019. 
Agro Pustaka, 1999. Ubi jalat tembus pasar Jepang, 21Juli 1999, 2 hlm.

Badan Pusat Statistik Provinsi Jambi. 2014. Luas Lahan, Produksi dan Produktivitas Ubi Jalar menurut Kabupaten/Kota. Jambi.

Badan Pusat Statistik Indonesia 2011. Produksi Ubi Jalar di Indonesia: Indonesia

Darmawi, H. 2005. Manajemen Risiko. Bumi Aksara. Jakarta.

Dinas Pertanian Tanaman Pangan Provinsi Jambi. 2012. Database Pertanian Provinsi Jambi 2008-2012. Jambi

Dinas Pertanian Tanaman Pangan Kabupaten Kerinci. Database Pertanian Kerinci 2012. Kerinci

Ditjend Hortikultura, 2010. "Pedum Pelaksanaan Pengembangan Hortikultura Tahun 2010.

Ginting,E and J.S. Utomo. 2010. Anthocyanis and Total Phenolic Contens of PupleFleshed Sweet Potato Cultivars and Their Antioxidant Activity. Paper Presented at the International Conference on Neuracetical and Fungtional Food in Denpasar, Nali on 12-15 th October 2010. 11p.

Handawi P.S. Rachman, dkk. 2010. Kajian Keterkaitan Produksi, Perdagangan dan Konsumsi Ubi Jalar untuk Meningkatkan $30 \%$ Partisipasi Konsumsi Mendukung Program Keanekaragaman Pangan dan Gizi.

Hasyim, A dan M. Jusup. 2008. Diversifikasi produk Ubi Jalar sebagai bahan pangan subsitusi beras. Sinar Tani Edisi 30 Juli - 5 Agustus 2008.

Jusup, M., Damanhuri., N. Basuki dan J. Resstuono, 2012. Perakitan varitea unggul dalam Wargiono dan Hermanto. Ubi jalar Inovasi Teknologi dan Prospek Pengembangan. Pusat Penelitian dan Pengembangan Tanaman Pangan. Balitbangtan. Hal.88-102.

Israwan, I. 2016. Analisis Keuntungan dan Nilai Tambah Pengolahan Ubi Kayu (Manihot Esculenta) Menjadi Tela-tela (Studi Kasus Usaha Tela Steak di Kelurahan Mandonga Kecamatan Mandonga Kota Kendari. Universitas Halu Oleo. Kendari.

Kadarsan, H, W. 1995. Keuangan Pertanian dan Pembiayaan Perusahaan Agribisnis. PT. Gramedia Pustaka Umum. Jakarta.

Kurnia, K. 2009. Yuk Makan Kudapan Sehat. Pusat Penelitian Bioteknologi Institut Bandung.

Suyamto, H. Sembiring, M Muchkis Adi dan J. Wagiono. 2012. Prospek dan

Kebijakan Pengembangan Ubi Jalar daqlm Wagiono dan Hermanto. Ubi Jalar Inovasi Teknoloogi dan Prospek Pengembangan. Pusat Penelitian dan Pengembangan Tanaman Pangan.Balitbangtan. Hal 103-114.

Soekartawi, Rusmadi dan Damaijadi. 1993. Risiko dan Ketidakpastian dalam Agribisnis, Teori dan Aplikasinya. Penerbit Rajawali Press. Jakarta.

Sudiyono, A. 2004. Pemasaran pertanian. UMM Press. Malang.

Purwono dan Purnamawati, Heni. 2013. Budidaya 8 Jenis Tanaman Pangan Unggul. PenebarSwadaya. Jakarta Timur 
Usman, Rianse dan Abdi. 2009. Metodologi Penelitian Sosial dan Ekonomi Teori dan Aplikasi. ALFABETA : Bandung

Nurmala, SD. 2011. Faktor-faktor yang Mempengaruhi Produksi Ubi Jalar (Studi Kasus : KelompokTani Hurip, Desa Cikarawang, Kecamatan Darmaga, Kabupaten Bogor). Bogor: Fakultas.Ekonomi dan Manajemen, Institut Pertanian Bogor. [skripsi]. (Diunduh dariRepository.ipb.ac.id/bitstream/ H11sdn.pdf). Diakses 13 September 2013

Nani Zuraida dan Yati Supriati. 2001. Usahatani Ubi Jalar sebagai Bahan Pangan Alternatif dan Diversisifikasi Sumber Karbohidrat. Balai Penelitian Bioteknologi Tanaman Pangan. Bogor.

New Weave (2002:170) dan Schuler (1986) Empowerment and the Law. ANALISIS SWOT (Kekuatan, Kelemahan, Kesempatan, Ancaman). Tools for Policy Impact: A Handbook for Researchers.

Peraturan Daerah Kabupaten Kuningan No. 11 Tahun 2005 Master Agropolitan Kabupaten Kuningan (cetak ulang) oleh Dinas Pertanian Kabupaten Kuningan Tahun 2007.

Purwono. 1988. Ubi kayu dan Ubi Jalar. Fakultas Pertanian Institut Pertanian Bogor. Bogor.

Saaty, Thomas L. 1993. "Pengembilan Keputusan Bagi Para Pemimpin". Terjemaahan : Liana Setiono. Jakarta. PT. Pustaka Binaman Pressindo.

Suprianto, Agus, 2007. "Perbandingan Kelayakan Jalan Beton dan Aspal dengan Metode Analytical Herarchy Process (Stu Kasus Jalan Raaya Demak-Godong)". Tesis Program Pasca Sarjana Universitas Diponegoro.

Susila, R. Wayan dan Ernawati Munadi, 2007. "Penggunaan Analitycal Hoerarchy Proces untuk Penyusunan Priorotas Proposal Penelitian". Informatika Petani Vol. 16 No 2 tahun 2007

Taher, A. Peran dan Strategi Pembangunan Industri Benih di Sumatera Barat. Prosiding Seminar Nasional BPTP Sumatera Barat. Kerjaama Balitbangda Sumatera Barat denan Balai Besar Pengkajian dan Pengembangan Teknologi Pertanian. Padang Sumatera Barat 25-26 Nopember 2005 Hal. 34-52. 